\title{
Itsenäistynyt Namibia tarvitsee tukea kasvatuksen kehittämiseen
}

\author{
Rauhankasvatusinstituutin pääsihteeri Helena \\ Kekkonen osallistui kutsuttuna vieraana Namibian \\ itsenäisyysjuhliin. Hänen käymässään keskustelussa \\ opetusministeri Nahas Angulan kanssa nousi esiin \\ Namibian tarve panostaa kasvatukseen ja koulutukseen. \\ Maa ei selviä kuitenkaan ilman ystäviä. Materiaalisen \\ avun lisäksi kaivataan opettajien ja kasvatusasian- \\ tuntijoiden kontakteja. Sen vuoksi ministeri Angula \\ toivoi Suomessa luotavan sisaroppilaitosrakennelman.
}

\section{Rauhankasvatusinstituutin piirissä ajatusta aletaan} konkretisoida jo kuluvan vuoden aikana.

Kun Afrikan viimeinen siirtomaa, Namibia, itsenäistyi 21.3.1990, maassa järjestettiin mahtavat kaksipäiväiset juhlallisuudet, joiden hyväksi kaikki ministeriöt, SWAPO:n toimisto ja lukemattomat vapaaehtoiset olivat työskennelleet kuukausia. Juhlien kustannusarvio oli 10 miljoonaa randia (15 miljoonaa markkaa), mikä oli saatu lähes kokonaan kerättyä kansainvälisiltä yhteisöiltä sekä namibialaisilta yrityksiltä ja yksityisiltä henkilöiltä. Kouluille annettiin kahden viikon itsenäisyysloma, ja kaikki tehtaat, laitokset ja liikkeet olivat kiinni kaksi päivää. Näinollen juhliin saattoi osallistua koko kansa.

Pääjuhla pidettiin Windhoekin stadionilla. Juhlinta alkoi jo edellisenä päivänä monipuolisella kulttuuriohjelmalla, jota oli saapunut seuraamaan täpötäysi katsomollinen kansalaisia, joukossa parisentuhatta ulkomaista vierasta. Mukana oli $\mathrm{mm}$. kaksikymmentä valtioiden päämiestä ja lukemattomia pää-, ulko- ym. ministereitä sekä poliittisia merkkihenkilöitä. Suosituimmat vieraat olivat $\mathrm{YK}: \mathrm{n}$ pääsihteeri Havier Perez de Cuellar ja Nelson Mandela puolisoineen.

Keskiyön lähestyessä Namibian presidentti Sam Nujoma, Etelä-Afrikan presidentti de
Afrikan lippu laskettiin alas, ja Namibian uusi lippu nostettiin salkoon kansan riemuitessa. Juhlinnan päättivät paraatit, erilaiset näytökset ja lopulta mahtava ilotulitus.

Kansanjuhlaa jatkettiin seuraavana päivänä ympäri maata: kaikki ministerit olivat puhujina eri kaupungeissa ja kylissä, ja ihmisille oli tarjolla juhlaruokaa yllinkyllin. Pääkaupungissa järjestettyyn kulkueeseen osallistui kymmeniä kouluja ja oppilaitoksia erilaisin näytöksin, yrityksiä ja kansalaisjärjestöjä omine esittelyineen sekä suuri joukko taiteilijoita. Kulkueen ohimarssi kesti yli kolme tuntia, ja sitä seurasi läpi kaupungin sankka yleisöjoukko. Iloinen, ja riemukas tunnelma vallitsi kaikkialla.

Arkipäivään osattiin juhlien jälkeen palata realistisesti. Yleisesti myönnettiin, että suuret vaikeudet ovat edessäpäin. Etelä-Afrikan lopetettua taloudellisen tukensa maassa on lähes kaikilla aloilla pula varoista: on asutettava 45000 kotimaahan palannutta pakolaista, yritettävä saada maattomille maata, työttömille työtä, on rakennettava uusia terveysklinikoita, sairaaloita, kouluja ja ennen kaikkea asuntoja. "'Ilman monien vuosien lujaa työntekoa ja uhrauksia emme selviä'. totesivat ministerit pu- 
heissaan. Kansainväliseen apuun luotettiin, jotta edes välttämättömimmät uudistustoimet saataisiin alkuun. Monikansallisia yhtymiä ei aiottu ainakaan alkuun kansallistaa eikä rikkailta valkoisilta ollut tarkoitus ottaa liikoja maita pois enempää kuin syrjäyttää heitä entisistä viroistaankaan.

Uudistussuunnitelmia leimasi sovittelunhalu: ' kansallisen sovinnon"' aikaansaamista pidettiin ensiarvoisena tehtävänä, jonka jälkeen muu kehitys voisi - valkoisten ja mustien yhteistyönä - käynnistyä.

Yhtenä kiireellisimmistä toimenpiterstä pidettiin kasvatuksen uudelleenjärjestelyä ja opettajainkoulutuksen tehostamista. Opetusministeri Nahas Angulan selvityksen mukaan mustien koulutuksellinen taso on surkea: maassa on $60-65$ prosenttia aikuisista luku- ja kirjoitustaidottomia. Kouluikäisistä lapsista 30-40 prosenttia ei pääse kouluun vanhempien köyhyyden, pitkien matkojen tai muiden syiden vuoksi.

Mustille tarkoitetuissa "bantukouluissa" on suuret luokat, huonot, usein kokonaan vailla opettajakoulutusta olevat opettajat, puutteelliset koulutarvikkeet ja usein pienilläkin lapsilla ylipitkät koulumatkat. Lisäksi opetusjärjestelmä perustuu ankaralle kilpailulle arvosanoista ja suorituksista, mikä vähentää sosiaalisesti heikoista oloista lähteneiden selviytymismahdollisuuksia.

Koulunkäyntiä vaikeuttaa suuresti myös se, että opetuskielenä ei ole lasten äidinkieli, vaan joko afrikaansi tai englanti sekä joissakin kouluissa saksa. Ylioppilastutkinnossa nuorten on suoritettava "äidinkielen" koe vieraalla kielellä.

Koulunsa keskeyttäneiden maara on em. syistä johtuen valtava. Esimerkiksi vuonna 1986 noin 69000 koulun aloittaneesta putosi kolmen ensimmäisen vuoden aikana pois 26000 lasta. Vuonna 1989 oli peruskoulun (9 v) viimeisellä luokalla noin 17000 koululaista ja lukion viimeisellä enää 3200 . Viimeksimainituista hylätään loppututkinnossa $30-70$ prosenttia, koulusta ja alueesta riippuen. '’Nääntymisprosentti", kuten viranomaiset asian ilmaisevat, on siis mustien koululaisten keskuudessa hälyttävä.

Opetusministeri kertoi myös, että noin 40 prosenttia peruskoulujen opettajista on joko lukionsa keskeyttäneitä tai loppututkinnossa hylättyjä, noin 30 prosentilla on 1--2 vuotta jatko-opintoja ja vain 30 prosentilla opettajien kolmivuotinen koulutus läpikäytynä.

Valkoisten lasten kouluolot ovat aivan päinvastaiset. Luokat ovat pieniä, koulut erinomaisesti varustetut: niissä on tarpeellisten opetusvälineiden lisäksi kirjastot, laboratoriot, asianmukaiset tietokoneet jne. Opettajilla on hyvä koulutus ja he saavat erinomaista palkkaa. Oppilaat opiskelevat alusta alkaen omalla äidinkielellään. Keskeyttämisiä ei tapahdu, vaan koko ikäluokka suorittaa 12-vuotisen koulun, jolloin heidän on helppo jatkaa korkeampia opintoja muiden maiden yliopistoissa.

Namibian koulujärjestelmässä on selvästi nähtävissä "'kolmannen maailman koulut" ja "ensimmäisen maailman koulut" rinnakkain, totesi opetusministeri, jonka ensisijaisena tehtävänä on tasoittaa mustien lasten koulutietä. Tämä ei tule tapahtumaan valkoisten koulujen tasoa pudottamalla, vaan muuttamalla vähitellen ',bantukoulut' edellisten kaltaisiksi ja avaamalla mustille lapsille ovet kaikiin kouluihin.

Koulun uudistamisen rinnalla Namibian opetusviranomaisia odottavat myös muut haasteet. Maassa on vain muutama harva ammatillinen oppilaitos ja ainoastaan Etelä-Afrikan yliopiston joitakin sivuosastoja Windhoekissa. Keskiasteen ammatillisten opintomahdollisuuksien luominen ja oman yliopiston kehittäminen (Lusakassa toimineen YK:n Namibiainstituutin pohjalta) sekä opettajainkoulutuksen kehittäminen ja laajentaminen ovat kiireisimmät tehtävät.

Odotukset ja toiveet ovat suuret, resurssit vähäiset. Sen vuoksi opetusministeri Nahas Angula esitti julkisen vetoomuksen kansainvälisille yhteisöille: '’Kasvatuksen nykyinen kriisi johtuu menneisyyden virheistä. Apartheidin vahinkojen korjaamiseksi tarvitaan muiden kansojen tukea." Taloudellinen apu on tarpeen koulujen rakentamiseen ja kunnostamiseen, asiantuntijoita tarvitaan opettajien pedagogiseen koulutukseen ja opintosuunnitelmien kehittämiseen. Lukioon kaivataan opettajavoimia: ennen kaikkea on puute englanninkielen, matematiikan ja luonnontieteiden opettajista sekä ammatillisten oppilaitosten kaikista opettajista.

Koulujen opetusvälineistä on huutava pula. Harvaanasutuille seuduille tarvitaan kulkuvälineitä lapsille ja esimerkiksi koulusta toiseen kiertäville opetusmateriaalia. Vammaiset ja ke- 
hitysvammaiset tarvitsevat opetusta jne. Kaikkinainen tuki ja pienetkin avustukset ovat tässä tilanteessa tervetulleita ja jopa välttämättömiä.

Suomen kouluille, yliopistojen kasvatustieteellisille tiedekunnille ja ammatillisille oppilaitoksille Nahas Angula lähetti erityisterveiset: Tukekaa Namibiaa hankkimalla "sisarkouluja" tai "sisaroppilaitoksia", joiden kanssa suorissa kontakteissa kukin koulu tai vastaava voi toimia juuri haluamallaan ja mainitulle laitokselle sopivilla tavoilla. Opettajien ja oppilaiden keskinäiset yhteydet ja mahdollinen vierailuvaihto ovat toivottuja - aina ei siis ole kyse pelkästään materiaalisesta avusta.
Ja kaikkein toivotuinta olisi rauhankasvatuskokemusten tunnetuksitekeminen Namibiaan, maahan, jonka on todella panostettava rauhanomaisten ratkaisujen käyttöön ristiriitatilanteissa, entisten "vihollisten" sopeuttamiseen yhteistyöhön ja kansallisen sovun rakentamiseen. Rauhankasvatusinstituutin ' Kasvatus rauhaa palvelemaan" -projekti aikookin lähivuosina avustaa namibialaisia opettajia järjestämällä heille muutaman viikon pituisia rauhankasvatuskursseja osin Suomessa, osin Namibiassa.

\section{HELENA KEKKONEN}

\section{ICAE:n kunniakirja Helena Kekkoselle}

Pääsihteeri Helena Kekkonen sai ICAE:n (The International Council for Adult Education) kunniakirjan järjestön IV maailmankokouksessa Bangkokissa. Huomionosoituksen perusteina pidettiin hänen osuuttaan aikuiskasvatuksen kansainvälisen liikkeen rakentamisessa. Helena Kekkonen oli keskeinen henkilö luotaessa vuonna 1981 Meeting in Finland -seminaarissa kansainvälinen rauhankasvatusverkosto, Peace Network, painotettaessa 1980-luvun Meeting in Finland -seminaarien sisällöt rauhankasvatukseen ja kehitettäessä Peaceletter-aikakauslehti sen nykyisessä muodossa.
Vapaan Sivistystyön Yhteisjärjestöi liittyi ICAE:hen vuonna 1976 ja muiden Pohjoismaiden vastaavat järjestöt vuosina 1977-78 Suomen esimerkkiä noudattaen ja Suomen aloitteesta. Myös tässä pääsihteeri Helena Kekkosen henkilökohtainen aktiivisuus on pantu ICAE:n piirissä merkille.

Bangkokin kokouksessa muistettiin kunniakirjalla kaikkiaan 16 aikuiskasvattajaa. Heidän joukossaan oli ICAE:n kunniapuheenjohtaja, köyhien pedagogiikkaa kehittänyt brasilialainen Paolo Freire. 